\title{
Influence of agronomic practices on severity of late blight of potato (Phytophthora infestans)
}

\author{
S. Dey ${ }^{*}$ and A. Chakraborty ${ }^{2}$ \\ ${ }^{1}$ Department of Plant Pathology, Bidhan Chandra Krishi Viswavidyalaya, Mohanpur, Nadia-741252(West \\ Bengal), INDIA \\ ${ }^{2}$ AICRP on Potato, Directorate of Research, Bidhan Chandra Krishi Viswavidyalaya, Kalyani, Nadia-741235 (West \\ Bengal), INDIA \\ *Corresponding author. E-mail: sdey.patho@gmail.com
}

Received: November 20, 2015; Revised received: March 26, 2016; Accepted: July 21, 2016

\begin{abstract}
An experiment was carried out to find out the influence of such agronomic practices on severity of the disease and to seek a proper cultural practice for management late blight of potato (Phytophthora infestans). The experimental results showed that the severity of late blight disease could be minimized by reducing the depth of irrigation (i.e. $1 / 4$ of irrigation channel). It was observed that the disease severity could be minimized by increasing the row-to-row and plant-to-plant spacing $(60 \times 25 \mathrm{~cm})$. It was also observed that when less than recommended dose of nitrogenous fertilizer $(200 \mathrm{Kg} \mathrm{N} / \mathrm{ha})$ along with slightly more than recommended dose of phosphorus and potassium fertilizer ( $200 \mathrm{Kg} \mathrm{P} \mathrm{O}_{5} / \mathrm{ha}$ and $250 \mathrm{Kg} \mathrm{K} 2 \mathrm{O} / \mathrm{ha}$ ) was applied, severity and spread of the disease was found to be under check. Therefore, for better management of late blight of potato the proper agronomic practices should be integrated with the application of fungicides. This will not only reduce the number of sprays but also reduces the health hazards owing to application of fungicides.
\end{abstract}

Keywords: Cultural management, Fertilizer dose, Irrigation, Late blight, Severity, Spacing

\section{INTRODUCTION}

Potato (Solanum tuberosum Linn), belonging to the family Solanaceae has established itself as an important non-cereal food crop in India. It is now cultivated in almost all the states under diverse agro-climatic condition except Kerala. It is a staple food in several countries particularly in Europe. Potato is the most popular crop in West Bengal next to cereals. Contribution of potato in agricultural GDP from unit area of cultivable land is about 3.7 times higher than rice and 5.4 times higher than wheat (Anonymous, 2015).

In field condition it has been observed critically that the incidence of several diseases affect the crop almost each and every year. Among them one of the important and devastating fungal disease is late blight. The disease caused by Phytophthora infestans (Mont.) de Bary which affects leaves and stems as well as tubers and causes heavy losses. The worldwide losses due to late blight are estimated at $€ 12$ billion (Haverkort et al., 2009). In India, losses caused by late blight ranges from 5-90\% depending upon the climatic conditions with an average of $15 \%$ across the country (Collins, 2000). For managing this disease a number of chemicals have been evaluated by different scientists and found to be effective. But it is an established fact that $P$. infestans develops resistance to systemic fungicides. Therefore management of the disease by altering cul- tural practices may be very effective in future (Miller et al., 2006; Perez and Forbes, 2010).

Therefore, the present investigation was carried out to know the influence of different agronomic practices like irrigation, spacing and different fertilizer doses on severity of the disease and the objective of the investigation was to find out the proper spacing, optimum dose of irrigation and fertilizer application which will be able to keep severity of the disease under check so that the less amount of fungicides needed to ultimately control the disease.

\section{MATERIALS AND METHODS}

The experiment was conducted at Adisaptagram Block Seed Farm, Mogra, Hooghly, West Bengal, India at 9.75m above sea level during 2010-2011 and 20112012 crop season following randomized block design (RBD). The potato variety Kufri Chandramukhi (KCM) was planted during mid of November in both the season. To study the influence of irrigation on severity of late blight four doses of irrigation was applied viz. $1 / 4$ of irrigation channel $\left(\mathrm{T}_{1}\right), 1 / 2$ of irrigation channel $\left(\mathrm{T}_{2}\right), 3 / 4$ of irrigation channel $\left(\mathrm{T}_{3}\right)$ and full of irrigation channel $\left(\mathrm{T}_{4}\right)$. The height of full irrigation channel was $15 \mathrm{~cm}$. At every irrigation dose severity of the disease was recorded at every seven days interval following the scale of Horsfall and Barrett (1945) as used in modified form (0-11) by a number of scientists 
(Shields et al., 1984; Tek, et al., 2004; Bock et al., 2009). For observing influence of spacing on disease development, field experiment was set by taking six spacing (row-to-row $\times$ plant-to-plant) viz. $50 \times 15 \mathrm{~cm}$ $\left(\mathrm{T}_{1}\right), 50 \times 20 \mathrm{~cm}\left(\mathrm{~T}_{2}\right), 50 \times 25 \mathrm{~cm}\left(\mathrm{~T}_{3}\right), 60 \times 15 \mathrm{~cm}$ $\left(\mathrm{T}_{4}\right), 60 \times 20 \mathrm{~cm}\left(\mathrm{~T}_{5}\right)$ and $60 \times 25 \mathrm{~cm}\left(\mathrm{~T}_{6}\right)$. The disease build up was recorded at every seven days interval. To observe the influence of fertilizer dose on disease development the field experiment was set by applying the following fertilizer doses in soil at the time of land preparation. These were as follows:

$$
\begin{gathered}
\mathrm{T}_{1}=\mathrm{N}_{200} \mathrm{P}_{150} \mathrm{~K}_{150} \\
\mathrm{~T}_{5}=\mathrm{N}_{200} \mathrm{P}_{150} \mathrm{~K}_{200} \\
\mathrm{~T}_{2}=\mathrm{N}_{225} \mathrm{P}_{150} \mathrm{~K}_{150} \\
\mathrm{~T}_{6}=\mathrm{N}_{200} \mathrm{P}_{200} \mathrm{~K}_{150} \\
\mathrm{~T}_{3}=\mathrm{N}_{250} \mathrm{P}_{150} \mathrm{~K}_{150} \\
\mathrm{~T}_{7}=\mathrm{N}_{150} \mathrm{P}_{150} \mathrm{~K}_{150} \\
\mathrm{~T}_{4}=\mathrm{N}_{200} \mathrm{P}_{200} \mathrm{~K}_{200} \\
\mathrm{~T}_{8}=\mathrm{N}_{200} \mathrm{P}_{200} \mathrm{~K}_{250}
\end{gathered}
$$

Finally, per cent disease intensity (PDI) values were calculated by using the formula developed by McKin- ney (1923).

\section{RESULTS AND DISCUSSION}

The results of the experiment are presented in Tables 1 -3 . From the results presented in Table 1 it is evident that late blight disease was increased with increasing irrigation dose and at the time of final observation PDI value of late blight reached maximum $(73.09 \%)$ in the plots applied with full recommended dose of irrigation (i.e. $\mathrm{T}_{4}$ ). This may be due to the microclimate of plant such as canopy temperature, soil temperature, soil moisture, canopy wetness etc. which influence the development of potato late blight. Higher depth of irrigation also may favour the spread of the disease into healthy plants. More late blight as well as tuber blight

\begin{tabular}{|c|c|c|c|c|c|}
\hline \multirow{2}{*}{ Treatments } & \multirow{2}{*}{ Irrigation } & \multicolumn{4}{|c|}{ PDI $^{1}$ of late blight (\%) } \\
\hline & & $7 \mathrm{DAI}^{2}$ & 14 DAI & 21 DAI & 28 DAI \\
\hline \multirow{2}{*}{$\mathrm{T}_{1}$} & \multirow{2}{*}{$1 / 4$ of irrigation channel } & $12.50^{* d}$ & $20.78^{\mathrm{d}}$ & $27.62^{\mathrm{d}}$ & $36.01^{\mathrm{d}}$ \\
\hline & & $(20.70)^{* *}$ & $(27.12)$ & $(31.70)$ & (36.88) \\
\hline \multirow{2}{*}{$\mathrm{T}_{2}$} & \multirow{2}{*}{$1 / 2$ of irrigation channel } & $20.75^{\mathrm{c}}$ & $29.35^{\mathrm{c}}$ & $38.61^{\mathrm{c}}$ & $45.41^{\mathrm{c}}$ \\
\hline & & $(27.10)$ & $(32.80)$ & $(38.41)$ & $(42.37)$ \\
\hline \multirow{2}{*}{$\mathrm{T}_{3}$} & \multirow{2}{*}{$3 / 4$ of irrigation channel } & $30.15^{b}$ & $39.52^{b}$ & $48.36^{\mathrm{b}}$ & $55.32^{\mathrm{b}}$ \\
\hline & & (33.30) & $(38.95)$ & $(44.06)$ & $(48.05)$ \\
\hline \multirow{2}{*}{$\mathrm{T}_{4}$} & \multirow{4}{*}{$\begin{array}{l}\text { Full of irrigation channel } \\
\text { (upto } 15 \mathrm{~cm} \text { height) }\end{array}$} & $39.63^{a}$ & $49.67^{a}$ & $63.18^{\mathrm{a}}$ & $73.09^{a}$ \\
\hline & & $(39.01)$ & $(44.81)$ & $(52.64)$ & $(58.76)$ \\
\hline $\mathrm{CD}(5 \%)$ & & 0.53 & 0.94 & 0.83 & 0.74 \\
\hline $\operatorname{SEm}( \pm)$ & & 0.17 & 0.30 & 0.27 & 0.24 \\
\hline
\end{tabular}
of potato was also observed with excess irrigation water (Rotem and Palti, 1969; Johnson et al., 2003).

From the results presented in Table 2 it is evident that the severity of the disease decreased with increase in spacing i.e. in spacing $50 \times 15 \mathrm{~cm}$ the severity of the

\begin{tabular}{|c|c|c|c|c|c|}
\hline \multirow{2}{*}{ Treatments } & \multirow{2}{*}{$\begin{array}{c}\text { Spacing }(\text { row } \times \text { plant }) \\
(\mathrm{cm} \times \mathrm{cm})\end{array}$} & \multicolumn{4}{|c|}{ PDI $^{1}$ of late blight (\%) } \\
\hline & & $7 \mathbf{D A I}^{2}$ & 14 DAI & 21 DAI & 28 DAI \\
\hline $\mathrm{T}_{1}$ & $50 \times 15$ & $\begin{array}{l}37.06 * \mathrm{a} \\
(37.50)^{* *}\end{array}$ & $\begin{array}{l}72.48^{\mathrm{a}} \\
(58.37)\end{array}$ & $\begin{array}{l}86.12^{\mathrm{a}} \\
(68.14)\end{array}$ & $\begin{array}{l}92.06^{\mathrm{a}} \\
(73.67)\end{array}$ \\
\hline $\mathrm{T}_{2}$ & $50 \times 20$ & $\begin{array}{l}27.45^{\mathrm{b}} \\
(31.59)\end{array}$ & $\begin{array}{l}61.28^{\mathrm{b}} \\
(51.52)\end{array}$ & $\begin{array}{l}80.40^{\mathrm{b}} \\
(63.73)\end{array}$ & $\begin{array}{l}88.25^{\mathrm{b}} \\
(69.98)\end{array}$ \\
\hline $\mathrm{T}_{3}$ & $50 \times 25$ & $\begin{array}{l}21.33^{\mathrm{c}} \\
(27.50)\end{array}$ & $\begin{array}{l}52.64^{\mathrm{d}} \\
(46.51)\end{array}$ & $\begin{array}{l}73.02^{\mathrm{d}} \\
(58.71)\end{array}$ & $\begin{array}{l}83.80^{\mathrm{c}} \\
(66.29)\end{array}$ \\
\hline $\mathrm{T}_{4}$ & $60 \times 15$ & $\begin{array}{l}20.91^{\mathrm{c}} \\
(27.21)\end{array}$ & $\begin{array}{l}56.42^{\mathrm{c}} \\
(48.69)\end{array}$ & $\begin{array}{l}80.18^{\mathrm{b}} \\
(63.59)\end{array}$ & $\begin{array}{l}87.52^{\mathrm{b}} \\
(69.32)\end{array}$ \\
\hline $\mathrm{T}_{5}$ & $60 \times 20$ & $\begin{array}{l}19.57^{\text {cd }} \\
(26.24)\end{array}$ & $\begin{array}{l}50.25^{\mathrm{e}} \\
(45.14)\end{array}$ & $\begin{array}{l}75.63^{c} \\
(60.42)\end{array}$ & $\begin{array}{l}80.30^{\mathrm{d}} \\
(63.65)\end{array}$ \\
\hline $\mathrm{T}_{6}$ & $60 \times 25$ & $\begin{array}{l}18.87^{\mathrm{d}} \\
(25.74)\end{array}$ & $\begin{array}{l}42.33^{\mathrm{f}} \\
(40.59)\end{array}$ & $\begin{array}{l}67.51^{\mathrm{e}} \\
(55.25)\end{array}$ & $\begin{array}{l}71.82^{\mathrm{e}} \\
(57.94)\end{array}$ \\
\hline $\mathrm{CD}(5 \%)$ & & 1.34 & 0.97 & 1.50 & 1.75 \\
\hline $\operatorname{SEm}( \pm)$ & & 0.44 & 0.32 & 0.50 & 0.58 \\
\hline
\end{tabular}
disease was $92.06 \%$. But in case of spacing $60 \times 25 \mathrm{~cm}$

Table 1. Effect of irrigation dose on severity of late blight of potato.

${ }^{1}$ PDI- Per cent Disease Intensity; ${ }^{2}$ DAI- Days After Initiation; * Values are mean of four replications; ** Values in parentheses are arcsine-transformed values;In a column, means followed by a common letter are not significantly different at the $5 \%$ level by DMRT.

Table 2. Effect on spacing on severity of late blight of potato.

${ }^{1}$ PDI- Per cent Disease Intensity; ${ }^{2}$ DAI- Days After Initiation; * Values are mean of four replications; ** Values in parentheses are arcsine-transformed values; In a column, means followed by a common letter are not significantly different at the $5 \%$ level by DMRT. 
Table 3. Effect on fertilizer dose on severity of late blight of potato.

\begin{tabular}{|c|c|c|c|}
\hline \multirow{2}{*}{$\begin{array}{l}\text { Treat- } \\
\text { ments }\end{array}$} & \multirow{2}{*}{$\begin{array}{l}\text { Fertilizer dose } \\
\left(\mathrm{Kg} \mathrm{ha}^{-1}\right)\end{array}$} & \multicolumn{2}{|c|}{ PDI $^{1}$ of late blight (\%) } \\
\hline & & $7 \mathrm{DAI}^{2}$ & 14 DAI \\
\hline $\mathrm{T}_{1}$ & $\mathrm{~N}_{200} \mathrm{P}_{150} \mathrm{~K}_{150}$ & $\begin{array}{c}26.54 * \mathrm{a} \\
(31.01)^{* *}\end{array}$ & $\begin{array}{c}37.43^{b} \\
(37.72)\end{array}$ \\
\hline $\mathrm{T}_{2}$ & $\mathrm{~N}_{225} \mathrm{P}_{150} \mathrm{~K}_{150}$ & $\begin{array}{c}27.28^{\mathrm{a}} \\
(31.48)\end{array}$ & $\begin{array}{l}40.18^{a} \\
(39.33)\end{array}$ \\
\hline $\mathrm{T}_{3}$ & $\mathrm{~N}_{250} \mathrm{P}_{150} \mathrm{~K}_{150}$ & $\begin{array}{l}27.96^{\mathrm{a}} \\
(31.91)\end{array}$ & $\begin{array}{r}41.87^{a} \\
(40.32)\end{array}$ \\
\hline $\mathrm{T}_{4}$ & $\mathrm{~N}_{200} \mathrm{P}_{200} \mathrm{~K}_{200}$ & $\begin{array}{l}17.99^{\mathrm{c}} \\
(25.08)\end{array}$ & $\begin{array}{l}29.73^{\mathrm{c}} \\
(33.04)\end{array}$ \\
\hline $\mathrm{T}_{5}$ & $\mathrm{~N}_{200} \mathrm{P}_{150} \mathrm{~K}_{200}$ & $\begin{array}{l}18.52^{\mathrm{c}} \\
(25.47)\end{array}$ & $\begin{array}{c}30.72^{c} \\
(33.66)\end{array}$ \\
\hline $\mathrm{T}_{6}$ & $\mathrm{~N}_{200} \mathrm{P}_{200} \mathrm{~K}_{150}$ & $\begin{array}{l}24.07^{\mathrm{b}} \\
(29.38)\end{array}$ & $\begin{array}{l}31.36^{\mathrm{c}} \\
(34.05)\end{array}$ \\
\hline $\mathrm{T}_{7}$ & $\mathrm{~N}_{150} \mathrm{P}_{150} \mathrm{~K}_{150}$ & $\begin{array}{l}25.78^{\mathrm{ab}} \\
(30.51)\end{array}$ & $\begin{array}{l}36.11^{\mathrm{b}} \\
(36.93)\end{array}$ \\
\hline $\mathrm{T}_{8}$ & $\mathrm{~N}_{200} \mathrm{P}_{200} \mathrm{~K}_{250}$ & $\begin{array}{l}17.78^{\mathrm{c}} \\
(24.93)\end{array}$ & $\begin{array}{l}26.52^{\mathrm{d}} \\
(30.99)\end{array}$ \\
\hline $\mathrm{CD}(5 \%)$ & & 1.31 & 1.20 \\
\hline $\operatorname{SEm}( \pm)$ & & 0.45 & 0.41 \\
\hline
\end{tabular}

${ }^{1}$ PDI- Per cent Disease Intensity; ${ }^{2}$ DAI- Days After Initiation; * Values are mean of four replications; ** Values in parentheses are arcsine-transformed values.; In a column, means followed by a common letter are not significantly different at the $5 \%$ level by DMRT.

the severity of the disease was only $71.82 \%$ and in case of spacing ranged from $15 \times 20 \mathrm{~cm}$ to $60 \times 20 \mathrm{~cm}$ the severity of the disease reduced gradually i.e. $88.25 \%, 83.80 \%, 87.52 \%$ and $80.30 \%$ respectively. Here also the microclimate inside the crop canopy had a marked effect on severity of the disease. The dense population also may favour the spread of the disease.

From the results presented in Table 3 it is evident that phosphorus $(\mathrm{P})$ and potassium $(\mathrm{K})$ had a marked effect on severity of potato late blight i.e. in fertilizer dose $\mathrm{N}_{200} \mathrm{P}_{200} \mathrm{~K}_{250}\left(\mathrm{~T}_{8}\right)$ only $26.52 \%$ of blight severity was observed 14 days after first appearance of the disease. This was followed by the fertilizer dose $\mathrm{N}_{200} \mathrm{P}_{200} \mathrm{~K}_{200}$ $\left(\mathrm{T}_{4}\right), \mathrm{N}_{200} \mathrm{P}_{150} \mathrm{~K}_{200}\left(\mathrm{~T}_{5}\right)$ and $\mathrm{N}_{200} \mathrm{P}_{200} \mathrm{~K}_{150}\left(\mathrm{~T}_{6}\right)$ where $29.73 \%, 30.72 \%$ and $31.36 \%$ of late blight was observed respectively. But in case of fertilizer dose with higher proportion of nitrogen $(\mathrm{N})$ the severity of late blight increased to a great extent i.e. in fertilizer dose $\mathrm{N}_{250} \mathrm{P}_{150} \mathrm{~K}_{150}\left(\mathrm{~T}_{3}\right)$ it was $41.87 \%$ and this was followed by ${ }_{225} \mathrm{P}_{150} \mathrm{~K}_{150}\left(\mathrm{~T}_{2}\right), \mathrm{N}_{200} \mathrm{P}_{150} \mathrm{~K}_{150}\left(\mathrm{~T}_{1}\right)$ and $\mathrm{N}_{150} \mathrm{P}_{150} \mathrm{~K}_{150}$ $\left(\mathrm{T}_{7}\right)$ where $40.18 \%, 37.43 \%$ and $36.11 \%$ of late blight was observed respectively. These findings are in line with Awan and Struchtemeyer (1957) who observed that increased $\mathrm{P}$ and $\mathrm{K}$ concentrations tend to lower late blight. Similarly, Rotem and Sari (1983), Carnegie and Colhoun (1983) and Phukan (1993) also observed the same findings that increased nitrogen level had the favourable influence on severity of late blight of potato. Reichbuch et al. (1977) and Sawicka (1993) also found higher infection with increased nitrogen fertilization. There are a number of direct and indirect effects of nitrogenous fertilization on the disease development. The direct effect results in susceptibility at the plant tissue level. Indirect effects of increased fertilization on late blight cause changing in canopy size. It may affect microclimate and which ultimately affect late blight, because, Phytophthora infestans is highly sensitive to temperature and humidity, especially humidity (Sharma, 2000; Basu and Maiti, 2007).

\section{Conclusion}

From the above study it may be concluded that higher depth of irrigation and dense plant population should be avoided to manage late blight of potato by cultural means. On the other hand application of higher doses of phosphorus and potassium fertilizer also lower the disease rate whereas higher dose of nitrogenous fertilize promote the disease.

\section{REFERENCES}

Anonymous (2015). Vision 2050. Central Potato Research Institute, Shimla. pp. 2.

Awan, A.B. and Struchtemeyer, R.A. (1957). The effect of fertilization on the susceptibility of potatoes to late blight. Am. Potato J. 34: 315-319.

Basu, A. and Maiti, M.K. (2007). Epidemiological study on late blight disease of potato caused by Phytophthora infestans in West Bengal. J. Mycopathol. Res. 45(1): 90-93.

Bock, C.H., Gottwald, T.R., Parker, P.E., Cook, A.Z., Ferrandino, F., Parnell, S. and van den Bosch, F. (2009). The Horsfall-Barratt scale and severity estimates of citrus canker. Eur. J. Plant Pathol. 125: 23-38.

Carnegie, S.F. and Colhoun, J. (1983). Effects of plant nutrition on susceptibility of potato leaves to Phytophthora infestans. Phytopathologische Zeitschrift. 108: 242-250.

Collins, W.W. (2000). The global initiative on late blightalliance for the future. Potato Global Research and Development Vol I. Indian Potato Association, CPRI, Shimla, India, pp. 513-524.

Haverkort, A.J., Struik, P.C., Visser, R.G.F. and Jacobsen, E. (2009). Applied biotechnology to combat late blight in potato caused by Phytophthora infestans. Potato Res. 52: $249-264$

Horsfall, J.G. and Barratt, R.W. (1945). An improved grading system for measuring plant diseases. Phytopathol. 35: 655 .

Johnson, D.A., Martin, M. and Cummings, T.F. (2003). Effect of chemical defoliation, irrigation water, distance from the pivot on late blight tuber rot in center-pivot irrigated potatoes in the Columbia basin. Plant Dis. 87: 977-982.

McKinney, H.H. (1923). Influence of soil temperature and moisture on infection of wheat seedling by Helminthosporium sativum. J. Agric. Res. 26: 195-217.

Miller, J., Nolte, P., Olsen, N., Miller, T., Bohl, B. and Thornton, M. (2006). Late blight management action plan for potatoes. University of Idaho Extension, Idaho Agricultural Experiment Station, pp. 1-11.

Perez, W. and Forbes, G. (2010). Technical Manual: Potato late blight. International Potato Center (CIP), pp. 1-36.

Phukan, S.N. (1993). Effect of plant nutrition on the incidence of late blight disease of potato in relation to plant 
age and leaf position. Indian J. Mycol. and Pathol. 23 (3): 287-290.

Reichbuch, L., Ignatescu, I. and Iacob, Gh. (1977). Aspecte noi privind sistemul de fertilizare si reactia cartofului la Phytophthora infestans (Mont.) de Bary (Mana) si Alternaria sp. (Patarea bruna a frunzelor). Lucrari Stiintifice. 8: 115-130.

Rotem, J. and Palti, J. (1969). Irrigation and plant diseases. Annu. Rev. Phytopathol. 8: 267-288.

Rotem, J. and Sari, A. (1983). Fertilization and ageconditioned predisposition of potatoes to sporulation of and infection by Phytophthora infestans. J. Plant Dis. Prot. 90(1): 83-88.

Sawicka, B. (1993). Zmiennosc pojawu i szerzenia sie zarazy ziemniaka (Phytophthora infestans (Mont.) de Bary) w warunkach ochrony plantacji i nawozenia azotem. Biuletyn Instytut Ziemniaka. 42: 113-122.

Sharma, K.K. (2000). Influence of meteorological factors on potato late blight development in North-western plains of India. J. Indian Potato Assoc. 27(1/2): 1-3.

Shields, E.J., Hygnstrom, J.R., Curwen, D., Stevenson, W.R., Wyman, J.A. and Binning, L.K. (1984). Pest management for potatoes in Wisconsin - a pilot program. Am. Potato J. 61(8): 508-515.

Tek, A.L., Stevenson, W.R., Helgeson, J.P. and Jiang, J. (2004). Transfer of tuber soft rot and early blight resistances from Solanum brevidens into cultivated potato. Theo. Appl. Genet. 109: 249-254. 